\title{
ANTIMICROBIAL ACTIVITY OF ESSENTIAL OILS AGAINST Listeria monocytogenes
}

\author{
Ružica M. Tomičić ${ }^{* 1}$, Ivana S. Čabarkapa ${ }^{2}$, Ana O. Varga ${ }^{2}$, Zorica M. Tomičić ${ }^{2}$ \\ ${ }^{1}$ University of Novi Sad, Faculty of Technology, 21000 Novi Sad, Bulevar cara Lazara 1, Serbia \\ ${ }^{2}$ University of Novi Sad, Institute of Food Technology, 21000 Novi Sad, Bulevar cara Lazara 1, Serbia
}

${ }^{*}$ Corresponding author:

Phone: +381214853667

E-mail address: ruzica.tomicic@yahoo.com; ruzica.tomicic@uns.ac.rs

ABSTRACT: Food poisoning caused by Listeria monocytogenes leads to a $30 \%$ rate of mortality among patients. The application of essential oils (EOs) to food products is a suitable strategy to control pathogens and to extend their shelf life by reducing microbial levels. The objective of this study was to evaluate the antimicrobial potential of essential oils (EOs) against $L$. monocytogenes. The EOs used in this study were caraway (Carum carvi), cinnamon (Cinnamomum zeylanicum), dill (Anethum graveolens), clove (Syzygium aromaticum), mentha (Menthae piperitae aetheroleum), red thyme (Thymus vulgaris), rosemary (Rosmarinus officinalis), common sage (Salvia officinalis), clary sage (Salvia sclarea) and summer savory (Satureja hortensis). The minimal inhibitory concentrations (MICs) of EOs were determined using the broth microdilution method. According to the MIC values, all essential oils were effective in the inhibition of $L$. monocytogenes strains, with MICs varying from 256 $\mu \mathrm{g} / \mathrm{ml}$ to $4096 \mu \mathrm{g} / \mathrm{ml}$. The results showed that cinnamon EO had the highest antimicrobial activity, while dill and mentha EOs were the least effective against the L. monocytogenes. In addition, two different procedures were carried out to test the effect of antibiotics gentamycin and streptomycin against the L. monocytogenes strains, the broth microdilution method and the MIC Test Strip. Our results indicated that the reference strain $L$. monocytogenes ATCC 19111 was much more sensitive to antibiotics than $L$. monocytogenes strains isolated from meat, highlighting that gentamycin was the more effective in comparison to streptomycin.

Key words: Listeria monocytogenes, antimicrobial activity, essential oils, antibiotics, broth microdilution method, MIC Test Strip

\section{INTRODUCTION}

Listeria monocytogenes is an important gram-positive foodborne pathogen which can cause the serious illness, listeriosis (Magalhães and Nitschke, 2012), which leads to a $30 \%$ rate of mortality among patients (Abdollahzadeh et al., 2014).One of its remarkable features is the ability to survive and grow in adverse conditions, such as high salt concentration, and low $\mathrm{pH}$ and temperature. These flexible growth conditions enhance its potential as a contaminant of food products. L. Monocytogenes has been found in a wide variety of food products as raw meat, raw vegetables, dairy products and read-to-eat food (Liu et al., 2017; McLauchlin et al., 2004; Tomičić et al., 2016; White et al., 2002). This bacteria is often linked to ready-to-eat food because it is able to grow at refrigeration temperatures and many outbreaks are associated with the consumption of these products (Gandhi 
and Chikindas, 2007; Liu, 2008). In spite of the various modern technologies and safety concepts such as HACCP, the control of this pathogen remains a major problem in food industry (Kramarenko et al., 2016; Liu et al., 2017).

One method for inhibiting or inactivating pathogenic bacteria to improve food safety is the use of antimicrobial food preservatives.

Nowadays, there is a consumer preference for healthy foodstuff without addition of chemical preservatives. Thus, the use of natural substances has shown particular promise, and many natural substances have been found to have antimicrobial properties.

One group of plant-derived natural products that has gained the interests of food industry to meet the consumers' preferences is essential oils (EOs).

Essential oils (EOs) are aromatic oily liquids produced from plant material, like leaves, seeds, flowers, roots and twigs (Burt, 2004).

These products have been widely used as flavouring agents in foods since the earliest recorded history. It is well known that many essential oils have antimicrobial activity against a wide range of spoilage and pathogenic bacteria (Burt, 2004; Chouhan et al., 2017; Nazzaro et al., 2013). However, data on the antimicrobial effect of essential oils on L. monocytogenes is still scarce.

Considering the above, the main objective of the present study was performed in order to evaluate the efficacy of EOs against $L$. monocytogenes.

\section{MATERIAL AND METHODS}

\section{Strains and growth conditions}

Two strains of L. monocytogenes 1 and 2 isolated from meat processing industry, and reference strain $L$. monocytogenes ATCC 19111 (lyophilized cultures of microorganisms, American Type Culture
Collection, Kwik-stickTM set, MicroBioLogics) were used in this study. The strains were preserved in Tryptone Soya Broth (TSB, HiMedia) supplemented with glycerol $(15 \%)$ at $-80{ }^{\circ} \mathrm{C}$ and revitalized from frozen stocks by cultivation on the Nutrient Agar (NA, HiMedia) plates for 2 days at 37 ${ }^{\circ} \mathrm{C}$ before performing the assays.

For the antimicrobial activity assays, a loopful of actively growing cells was suspended in Mueller Hinton Broth (MHB, HiMedia) and adjusted to $0.5 \mathrm{McF}$ arland standard turbidity to achieve a final cell concentration of $1 \times 10^{6}$ cells $/ \mathrm{ml}$.

\section{Essential oils (EOs)}

The EOs used in this study were caraway (Carum carvi), cinnamon (Cinnamomum zeylanicum), dill (Anethum graveolens), clove (Syzygium aromaticum), mentha (Menthae piperitae aetheroleum), red thyme (Thymus vulgaris), rosemary (Rosmarinus officinalis), common sage (Salvia officinalis), clary sage (Salvia sclarea) and summer savory (Satureja hortensis). All EOs were obtained from Institute of Field and Vegetable Crops in Novi Sad and stored in the refrigeration before use.

\section{Antimicrobial susceptibility testing}

To determine the minimal inhibitory concentrations (MICs) of plant essential oils (EOs) and antibiotics, the broth microdilution method was used as described before (Klančnik et al., 2009).

Briefly, stock solutions of plant EOs were prepared by dissolving the oils in Mueller Hinton Broth to a concentration of 80.00 $\mathrm{mg} / \mathrm{ml}$ and further diluted in MHB to a working solution of $32.768 \mathrm{mg} / \mathrm{ml}$.

Afterwards, $200 \mu \mathrm{l}$ of working solution was pipetted to the first row of a 96-well microtiter plate (Eppendorf, Germany) and serial dilutions were performed to reach final concentrations ranging from 16384 $\mu \mathrm{g} / \mathrm{ml}$ to $16 \mu \mathrm{g} / \mathrm{ml}$. Gentamycin sulfate (AppliChem, Darmstadt, Germany) and Streptomycin sulphate BioChemica (AppliChem, Darmstadt, Germany) were used as antimicrobial standards. 
Final concentrations of gentamycin and streptomycin were in the range from 16$0.0156 \mu \mathrm{g} / \mathrm{ml}$ and $32-0.0313 \mu \mathrm{g} / \mathrm{ml}$, respectively. After twofold serial dilutions by MHB across the plate, each well was inoculated with $100 \mu \mathrm{l}$ of L. monocytogenes activated culture (ca. $1 \times 10^{6}$ cells $/ \mathrm{ml}$ ) and plates were incubated for 24 h at $37^{\circ} \mathrm{C}$.

After incubation, $20 \mu \mathrm{l}$ resazurin aqueous solution was added to each well. Microplates were incubated for $24 \mathrm{~h}$ at $37^{\circ} \mathrm{C}$. The concentration that completely inhibited bacterial growth in the microtitar plate ad oculos (MIC) was the concentration from first nonturbid well at which the blue color did not change into pink.

Wells with culture medium, with the bacterial suspension only, plant essential oils and antibiotics only, were used as control. Four replicates were run for each EO and antibiotic.

\section{MIC Test Strip}

The MIC Test Strip was used for determination of the minimal inhibitory concentrations of gentamycin and streptomycin against $L$. monocytogenes strains and performed according to the procedures of manufacturer Liofilchem (Via Scozia, Zona Industriale - Reseto Italy).

Briefly, $200 \mu \mathrm{l}$ of each L. monocytogenes suspension (ca. $1 \times 10^{6} \mathrm{cells} / \mathrm{ml}$ ) was added to a sterile petri dish and $20 \mathrm{ml}$ of Mueller Hinton Agar (MHA, HiMedia) was poured, homogenized and left to tighten.

After drying the surfaces of the plates, a sterile porous strips (Liofilchem, Italy) with a predefined concentration gradient of antibiotics gentamycin and streptomycin was applied on the surface of each inoculated agar surface.

After 24 hours incubation at $37^{\circ} \mathrm{C}$, a symmetrical inhibition ellipse centered along the strip was formed. The MIC was read directly from the scale in terms of $\mu \mathrm{g} / \mathrm{ml}$ at the point where the edge of the inhibition ellipse intersects the strip MIC Test Strip.

\section{RESULTS AND DISCUSSION}

In recent years there has been a growing interest in researching and developing new antimicrobial agents from various sources to combat microbial resistance.

The antimicrobial activity of plant essential oils (EOs) has formed the basis of many applications, including raw and processed food preservation, pharmaceuticals, alternative medicine and natural therapies (Chouhan et al., 2017; Nazzaro et al., 2013).

An exhaustive review of the literature shows that there is a lack of studies on the antibacterial activity of the EOs against $L$. monocytogenes. This study intends to contribute toward filling some gaps in the current knowledge.

In the present study, the effect of the ten EOs was examined against the foodborne pathogenic bacteria $L$. monocytogenes by the broth microdilution methods (Tables 1).

The application of the broth microdilution method is useful to compare the antibacterial effect between EOs and to identify the minimal concentrations of EO that did not allow bacterial replication (Mazzarrino et al. 2015).

Considerable inhibitory effect of the tested EOs on the L. monocytogenes was found, with MICs varying from $256 \mu \mathrm{g} / \mathrm{ml}$ to 4096 $\mu \mathrm{g} / \mathrm{ml}$ as presented in Table 1 . Among the ten essential oils, caraway, cinnamon and mentha EOs exhibited a similar antimicrobial spectrum on the tested bacteria.

However, cinnamon EO showed the highest activity, inhibiting the strains at the MIC value of $256 \mu \mathrm{g} / \mathrm{ml}$. The strongest antibacterial activity of cinnamon EO is possibly due to its major constituents.

The most active constituents of many EO with wide spectra of antimicrobial activity are likely the aromatic phenolic compounds, such as cinnamic aldehyde in cinnamon, eugenol in clove and cin- 
namon, thymol and carvacrol in thyme (Desai et al., 2012; Shan et al., 2007).

These bioactive principles in the related dietary spices and medicinal herbs were also identified in other studies (Chauhan et al., 2007; Zampini et al., 2005). Some studies claim that the phenolic compounds present in spices and herbs might also play a major role in their antimicrobial effects (Hara-Kudo et al., 2004).

In our contribution, data also indicate that essential oils of red thyme, clove and summer savory exhibited a significant inhibitory effect on the reference strain $L$. monocytogenes ATCC 19111.

Worthy of note is the fact that strains isolated from meat were more resistant to these essential oils as compared to $L$. Monocytogenes ATCC 19111. On the other hand, results clearly demonstrate that dill and mentha EOs (MICs of 4096 $\mu \mathrm{g} / \mathrm{ml}$ ) showed the lowest antibacterial activity among all tested EOs.

In addition, according to our findings common sage EO was less effective than clary sage $\mathrm{EO}$, although it reduced the bacterial counts.

Generally, most published results demonstrate that the observed variation in antibacterial ac-tivities of among EOs is due to at least two factors: 1) the major components of EOs, and 2) the type of bacteria tested (Bakkali et al., 2008; Burt, 2004; Rather et al., 2012).

Interestingly, for some plant oils such as clove and sage, there has been some research and reporting of toxic and irritant properties (Bansod and Rai, 2008; Hammer et al., 1999). In spite of this, most of these oils are available for purchase as whole oils or as part of pharmaceutical or cosmetic products, indicating that toxic properties do not prohibit their use.

Listeria spp. are often exposed to low levels of antibiotics, as these agents are used in large amounts both in human and animal medicine (Aarestrup 2012). In the present study, the effect of antibiotics gentamycin and streptomycin was examined against the $L$. monocytogenes strains as presented in Table 2.

The results showed that the reference strain L. monocytogenes ATCC 19111 was much more sensitive to antibiotics than L. monocytogenes strains isolated from meat. Many mechanisms exist by which bacteria can become resistant to antimicrobial agents.

Although mutational events are important in the development of resistance to some agents, by far the most important factor in resistance is extrachromosomal genetic material in the form of plasmids.

Important mechanisms of bacterial resistance to antibiotics are interference with the transport of the antimicrobial agents into the bacterial cell, inactivation of the agent, and alteration of the target site or metabolic pathway by the microorganism (Neu, 1982).

We should mention that resistance of $L$. monocytogenes strains isolated from meat in comparison with $L$. monocytogenes ATCC 19111 undoubtedly reflects inherent physiological differences between strains.

As expected, gentamycin was the most effective against all tested $L$. monocytogenes strains, which is consistent with earlier reports ( $\mathrm{Li}$ et al., 2006; Al-Nabulsi et al., 2015). L. monocytogenes rarely develops acquired resistance to antibiotics.

However, some studies have recently reported an increased rate of resistance of $L$. monocitogenes strains to antibiotics due to mutations or acquisition of mobile genetic elements (Bertsch et al., 2014; Conter et al., 2009; Morvan et al., 2010).

The Test Strip and broth microdilution results for tested antibiotic standards were compared in this study. 
Table 1.

Antimicrobial acitivity of plant essential oils expressed as MIC, determined by the broth microdilution test

\begin{tabular}{|c|c|c|c|c|}
\hline \multirow[t]{2}{*}{ Plant species } & \multirow[t]{2}{*}{ Common name } & $\begin{array}{c}L . \\
\text { monocytogenes } \\
\text { ATCC } 19111\end{array}$ & $\begin{array}{c}L . \\
\text { monocytogenes } \\
1\end{array}$ & $\begin{array}{c}L . \\
\text { monocytogenes } \\
2\end{array}$ \\
\hline & & & $\begin{array}{c}\text { MIC } \\
(\mu \mathrm{g} / \mathrm{ml})\end{array}$ & \\
\hline $\begin{array}{l}\text { Anethum } \\
\text { graveolens }\end{array}$ & dill & 4096 & 4096 & $>16384$ \\
\hline Carum carvi & caraway & 1024 & 1024 & 1024 \\
\hline $\begin{array}{l}\text { Cinnamomum } \\
\text { zeylanicum }\end{array}$ & cinnamon & 256 & 256 & 256 \\
\hline $\begin{array}{l}\text { Menthae piperitae } \\
\text { aetheroleum }\end{array}$ & mentha & 4096 & 4096 & 4096 \\
\hline $\begin{array}{l}\text { Rosmarinus } \\
\text { officinalis }\end{array}$ & rosemary & 2048 & 2048 & 512 \\
\hline Salvia officinalis & common sage & 4096 & 1024 & 1024 \\
\hline Salvia sclarea & clary sage & 2048 & 512 & 512 \\
\hline Satureja hortensis & summer savory & 256 & 512 & 512 \\
\hline $\begin{array}{l}\text { Syzygium } \\
\text { aromaticum }\end{array}$ & clove & 512 & 1024 & 1024 \\
\hline Thymus vulgaris & red thyme & 256 & 1024 & 1024 \\
\hline
\end{tabular}

Table 2.

Antimicrobial acitivity of antibiotics expressed as MIC, determined by the broth microdilution test and Test Strip

\begin{tabular}{|c|c|c|c|c|c|c|}
\hline \multirow{2}{*}{ Antibiotics } & $\begin{array}{c}L . \\
\text { monocytogenes } \\
\text { ATCC } 19111\end{array}$ & & $\begin{array}{c}L . \\
\text { monocytogenes } \\
1\end{array}$ & & $\begin{array}{c}L . \\
\text { monocytogenes } \\
2\end{array}$ & \\
\hline & $\begin{array}{l}\text { Micro- } \\
\text { dilution } \\
\text { MIC }_{\text {mdil }}\end{array}$ & $\begin{array}{l}\text { Test } \\
\text { Strip } \\
M_{\mathrm{II}}\end{array}$ & $\begin{array}{l}\text { Micro- } \\
\text { dilution } \\
\text { MIC }_{\text {mdil }}\end{array}$ & $\begin{array}{l}\text { Test } \\
\text { Strip } \\
\text { MIC }_{\text {ts }}\end{array}$ & $\begin{array}{l}\text { Micro- } \\
\text { dilution } \\
\text { MIC }_{\text {mdil }}\end{array}$ & $\begin{array}{l}\text { Test } \\
\text { Strip } \\
\text { MIC }_{\mathrm{ts}}\end{array}$ \\
\hline Gentamycin & 0.25 & 0.19 & 0.5 & 0.38 & 0.5 & 0.38 \\
\hline Streptomycin & 4 & 1 & 8 & 2 & 8 & 6 \\
\hline
\end{tabular}

The results in Table 2 show that the MICs obtained by different methods differed significantly. All isolates tested were sensitive to gentamycin and streptomycin.

However, the minimal inhibitory concentration $\left(\mathrm{MIC}_{\text {mdil }}\right)$ of both gentamycin and streptomycin determined with dilution method was higher than the minimal inhibitory concentration $\left(\mathrm{MIC}_{\mathrm{ts}}\right)$ determined with Test Strip.

All methods were equally suitable for the testing of the sensitivity of $L$. monocytogenes to antibiotics.
Thus, the broth microdilution method appears to be an easy and reliable method for determination of the MICs of antibiotics for $L$. monocytogenes.

\section{CONCLUSIONS}

In conclusion, the current study emphasizes a significant potential of essential oils as antimicrobial agents against $L$. monocytogenes. In fact, our findings open up new perspectives on the application of EOs as biopreservatives against foodborne pathogens. 
The tested essential oils may contain antimicrobial constituents, and further phytochemical and pharmacological studies will be necessary to isolate the active constituents and evaluate the antimicrobial activity against a wide range of microbial populations.

\section{ACKNOWLEDGEMENTS}

This paper is a result of the research within the project "Microbiological risks from vegetables in the area of AP Vojvodina" financed by the Provincial secretariat for higher education and scientific research, Autonomous Province of Vojvodina, Republic of Serbia.

\section{REFERENCES}

1. Aarestrup, F. (2012). Sustainable farming: get pigs off antibiotics. Nature, 486, 465466.

2. Abdollahzadeh, E., Rezaei, M., Hosseini, H. (2014). Antibacterial activity of plant essential oils and extracts: The role of thyme essential oil, nisin, and their combination to control Listeria monocytogenes inoculated in minced fish meat. Food Control, 35, 177-183.

3. Al-Nabulsi, A.A., Osaili, T.M., Shaker, R.R., Olaimat, A.N., Jaradat, Z.W., Elabedeen, N.A. Z., Holley, R.A. (2015). Effects of osmotic pressure, acid, or cold stresses on antibiotic susceptibility of Listeria monocytogenes. Food Microbiology, 46, 154160.

4. Bakkali, F., Averbeck, S., Averbeck, D., Idaomar, M. (2008). Biological effects of essential oils-a review. Food and Chemical Toxicology, 46, 446-475.

5. Bansod, S., Rai, M. (2008). Antifungal activity of essential oils from Indian medicinal plants against human pathogenic Aspergillus fumigatus and $A$. niger. World Journal of Medical Sciences, 3 (2), 81-88.

6. Bertsch, D., Muelli, M., Weller, M., Uruty, A., Lacroix, C., Meile, L. (2014). Antimicrobial susceptibility and antibiotic resistance gene transfer analysis of foodborne, clinical, and environmental Listeria spp. isolates including Listeria monocytogenes. Microbiology Open, 3 (1), 118-127.
7. Burt, S. (2004). Essential oils: their antibacterial properties and potential applications in foods-a review. International Journal of Food Microbiology, 94, 223253.

8. Chauhan, A.T., Negi, P.S., Ramteke, R.S. (2007). Antioxidant and antibacterial activities of aqueous extract of Seabuckthorn (Hippophae rhamnoides) seeds. Fitoterapia, 78, 590-592.

9. Chouhan, S., Sharma K., Guleria, S. (2017). Antimicrobial activity of some essential oils-present status and future perspectives. Medicines, 4, 1-23.

10. Conter, M., Paludi, D., Zanardi, E., Ghidini, S., Vergara, A., Ianieri, A. (2009). Characterization of antimicrobial resistance of foodborne Listeria monocytogenes. International Journal of Food Microbiology, 128, 497-500.

11. Desai, M.A., Soni, K.A., Nannapaneni, R., Schilling, M.W., Silva, J.L. (2012). Reduction of Listeria monocytogenes in raw catfish fillets by essential oils and phenolic constituent carvacrol. Journal of Food Science, 77, 516-522.

12. Gandhi, M., Chikindas, M.L. (2007). Listeria: a foodborne pathogen that knows how to survive. International Journal of Food Microbiology, 113, 1-15.

13. Hammer, K.A., Carson, C.F., Riley, T.V. (1999). Antimicrobial activity of essential oils and other plant extracts. Journal of Applied Microbiology, 86, 985-990.

14. Hara-Kudo, Y., Kobayashi, A., Sugita-Konishi, Y., Kondo, K. (2004). Antibacterial activity of plants used in cooking for aroma and taste. Journal of Food Protection, 67, 2820-2824.

15. Nazzaro, F., Fratianni, F., Martino, L.D., Coppola, R., Feo, V.D. (2013). Effect of essen-tial oils on pathogenic bacteria. Pharmaceuticals, 6, 1451-1474.

16. Klančnik, A., Guzej, B., Kolar, M.H., Abramovič, H., Možina, S.S. (2009). In vitro antimicrobial and antioxidant activity of commercial rosemary extract formulations. Journal of Food Protection, 72, 1744-1752.

17. Kramarenko, T., Roasto, M., Keto-Timonen, R., Maesaar, M., Meremae, K., Kuningas, M., Horman A., Korkeala $\mathrm{H}$. (2016). Listeria monocytogenes in readyto-eat vacuum and modified atmosphere 
packaged meat and fish products of Estonian origin at retail level. Food Control, $67,48-52$.

18. Li, Q., Sherwood, J.S., Logue, C.M. (2006). Antimicrobial resistance of Listeria spp. Recovered from processed bison. Letters in Applied Microbiology, 44, 86-91.

19. Liu, D. (2008). Epidemiology. In Handbook of Listeria monocytogenes. Ed. D. Liu, Taylor and Francis, Boca Raton, pp. 2759.

20. Liu, G., Ren, G., Zhao, L., Cheng, L., Wang, C., Sun, B. (2017). Antibacterial activity and mechanism of bifidocin A against Listeria monocytogenes. Food Control, 73, 854-861.

21. Magalhães, L., Nitschke, M. (2012). Antimicrobial activity of rhamnolipids against Listeria monocytogenes and their synergistic interaction with nisin. Food Control, 29, 138-142.

22. Mazzarrino, G., Paparella, A., Chaves-López, C., Faberi, A., Sergi, M., Sigismondi, C., Compagnone, D., Serio, A. (2015). Salmonella enterica and Listeria monocytogenes inactivation dynamics after treatment with selected essential oils. Food Control, 50, 794-803.

23. McLauchlin, J., Mitchell, R.T., Smerdon, W.J., Jewell, K. (2004). Listeria monocytogenes and listeriosis: A review of hazard characterisation for use in microbiological risk assessment of foods. International Journal of Food Microbiology, 92, 15-33.

24. Morvan, A., Moubareck, C., Leclercq, A., Hervé-Bazin, M., Bremont, S., Lecuit, M., Courvalin, P., Le Monnier, A. (2010). An- timicrobial resistance of Listeria monocytogenes strains isolated from humans in France. Antimicrobial Agents and Chemotherapy, 54 (6), 2728-2731.

25. Nazzaro, F., Fratianni, F., Martino, L.D., Coppola, R., Feo, V.D. (2013). Effect of essential oils on pathogenic bacteria. Pharmaceuticals, 6, 1451-1474.

26. Neu, H.C. (1982). Mechanisms of bacterial resistance to antimicrobial agents, with particular reference to cefotaxime and other betalactam compounds. Reviews of Infectious Diseases, 4, 288-299.

27. Rather, M.A., Dar, B.A., Dar, M.Y., Wani, B.A., Shah, W.A., Bhat, B.A., Ganai B.A., Bhat K.A., Anand, R., Qurishi M.A. (2012). Chemical composition, antioxidant and antibacterial activities of the leaf essential oil of Juglans regia L. and its constituents. Phytomedicine, 19, 1185-1190.

28. Shan, B., Cai, Y.Z., Brooks, J.D., Corke, $\mathrm{H}$. (2007). The in vitro antibacterial activity of dietary spice and medicinal herb extracts. International Journal of Food Microbiology, 117, 112-119.

29. Tomičić, R., Čabarkapa, I., Vukmirović, Đ., Lević, J., Tomičić, Z. (2016). Influence of growth conditions on biofilm formation of Listeria monocitogenes. Food and Feed Research, 43 (1), 19-24.

30. White, D.G., Zhao, S., Simjee, S., Wagner, D.D., McDermott, P.F. (2002). Antimicrobial resistance of foodborne pathogens. Microbes and Infection, 4, 405-412.

31. Zampini, I.C., Vattuone, M.A., Isla, M.I. (2005). Antibacterial activity of Zuccagnia punctata Cav. ethanolic extracts. Journal of Ethnopharmacology, 102, 450-456. 


\title{
АНТИМИКРОБНА АКТИВНОСТ ЕТАРСКИХ УЉА НА Listeria monocytogenes
}

\author{
Ружица М. Томичић* ${ }^{1}$, Ивана С. Чабаркапа ${ }^{2}$, Ана О. Варга ${ }^{2}$, Зорица М. Томичић ${ }^{2}$ \\ ${ }^{1}$ Универзитет у Новом Саду, Технолошки фракултет, 21000 Нови Сад, Булевар цара Лазара бр. \\ 1, Србија \\ ${ }^{2}$ Универзитет у Новом Саду, Институт за прехрамбене технологије у Новом Саду, 21000 Нови \\ Сад, Булевар цара Лазара бр. 1, Србија
}

Сажетак: Тровање храном изазвано бактеријом Listeria monocytogenes доводи до $30 \%$ стопе смртности међу пацијентима. Примена етарских уља (EOc) у прехрамбеним производима је погодна стратегија за контролу патогена и продужење њиховог рока трајања смањењем нивоа микроба. Циљ ове студије је био да се процени антимикробни потенцијал етарских уља (EOc) на L. monocytogenes. EOc коришћена у овој студији била су ким (Carum carvi), цимет (Cinnamomum zeylanicum), мирођија (Anethum graveolens), каранфилић (Syzygium aromaticum), нана (Menthae piperitae aetheroleum), црвени тимијан (Thymus vulgaris), рузмарин (Rosmarinus officinalis), зачинска жалфрија (Salvia officinalis), мускатна жалфија (Salvia sclarea) и вртни чубар (Satureja hortensis). Минимална инхибиторна концентрација етарских уља је одређена коришћењем микродилуционе методе. Према добијеним вредностима МIC, сва етарска уља су била ефикасна у инхибицији сојева L. monocytogenes, са вредностима MIC од $256 \mu \mathrm{g} / \mathrm{ml}$ до 4096 $\mu \mathrm{g} / \mathrm{ml}$. Резултати су показали да је етарско уље цимета испољило највишу антимикробну активност на сојеве L. monocytogenes, док су мирођија и нана били најмање ефикасни. Поред тога, спроведене су две различите процедуре у циљу испитивања утицаја антибиотика гентамицина и стрептомицина на сојеве L. monocytogenes, коришћене су микродилуциона метода и MIC Test Strip. Наши резултати указују да је рефрерентни coj $L$. monocytogenes ATCC 19111 био знатно осетљивији на антибиотике у поређењу са сојевима L. monocytogenes изолованим из меса, наглашавајући већу ефикасност гентамицина у односу на стрептомицин.

Кључне речи: Listeria monocytogenes, антимикробна активност, етарска уља, антибиотици, микродилуциони метод, MIC Test Strip

Received: 27 April 2018

Received in revised form: 18 May 2018

Accepted: 25 May 2018 